\title{
Advanced non-small cell lung cancer - Treatment with Pembrolizumab
}

\author{
Participants: \\ id Antonio Silvinato ${ }^{1}$ \\ Idevaldo Floriano ${ }^{1}$ \\ Wanderley Marques Bernardo²
}

Created on: June 3, 2019

1. Associação Médica Brasileira, São Paulo, SP, Brasil 2. Coordenador do Programa Diretrizes da Associação Médica Brasileira, São Paulo, SP, Brasil

E-mail:wmbernardo@usp.br

The Guidelines Project, an initiative of the Brazilian Medical Association, aims to combine information from the medical field in order to standardize producers to assist the reasoning and decision-making of doctors.

The information provided through this project must be assessed and criticized by the physician responsible for the conduct that will be adopted, depending on the conditions and the clinical status of each patient.

Lung cancer is the worldwide leading cause of cancer-related deaths in both genders. Pembrolizumab is a IgG4 monoclonal antibody, which is highly selective, humanized, and binds to the programmed cell death protein 1 (PD-1) receptor and blocks its interaction with the PD-L1and PD-L2 ligands. We conducted a systematic review of the literature, without time restrictions, in the Medline database, using the following PICO: Adult patients with advanced NSCLC; Treatment with pembrolizumab alone or associated with chemotherapy, compared with chemotherapy, except for monochemotherapy with docetaxel and death outcomes (due to any cause) and adverse events. We selected 244 papers to answer the clinical question. The details of the methodology and the results of this guideline are set out in Annex 1.

\section{INTRODUCTION}

Lung cancer is the worldwide leading cause of cancer-related deaths in both genders, and smoking is its main etiological factor. The discovery of immunological checkpoints corroborates the hypothesis that ligands present in the tumor modulate the carcinogenesis mechanisms and immune activity of the tumor microenvironment. Among the most studied coregulatory molecules, the PD-1 (programmed cell death 1) and its ligand PD-L1 (programmed cell death ligand 1) stand out.

The PD-1 is a immunologic checkpoint that limits the activity of $\mathrm{T}$ cells (lymphocytes) in peripheral tissues. The PD-1 pathway is a immunological control checkpoint that can be coupled by tumor cells to inhibit immune surveillance of the active $\mathrm{T}$ cell.

Pembrolizumab is a IgG4 monoclonal antibody that is highly selective, humanized, and binds to the programmed cell death protein 1 (PD-1) receptor and blocks its interaction with the PD-L1 and PD-L2 ligands, which are expressed in antigen-presenting cells and may be expressed by tumors or other cells in the tumor microenvironment, assisting them in preventing of their detection and elimination by the 
immune system of the host.

Non-small cell lung neoplasms, without mutations in the epidermal growth factor receptor (EGFR) gene or rearrangement of the anaplastic lymphoma kinase $(A L K)$ gene, with gene expression for PD-L1, are the target of pembrolizumab.

\section{RESULTS}

Our study population included a total of 2,877 patients with NSCLC, submitted to pembrolizumab therapy $(\mathrm{N}=791)$ and compared to chemotherapy $(\mathrm{N}=788)$, or pembrolizumab plus chemotherapy $(\mathrm{N}=748)$ compared with chemotherapy $(\mathrm{N}=550)$, and followed-up to measure the death and adverse events outcomes for 12 months (Table 1 - Annex I).

Regarding the bias risk of the five studies included, three of them were not double-blind ${ }^{1-3}$, so the overall risk of the studies can be considered low (Table 2 Annex I).

\section{META-ANALYSIS}

Two RCTs ${ }^{\mathbf{1 . 2}}$ present sufficient data to allow for a meta-analysis, considering results (number of deaths) up to 12 months, comparing pembrolizumab with chemotherapy in advanced NSCLC (Table 3).

TABLE 3. MORTALITY RATE IN 12 MONTHS PEMBROLIZUMAB VS. CHEMOTHERAPY.

\begin{tabular}{l|l|l|l} 
Study & $\begin{array}{l}\text { Pembro } \\
\text { Patients/ } \\
\text { Events }\end{array}$ & $\begin{array}{l}\text { Carboplatin + } \\
\text { pemetrexed or } \\
\text { paclitaxel } \\
\text { Patients/Events }\end{array}$ & $\begin{array}{l}\text { * Platinum-based } \\
\text { chemotherapy } \\
\text { Patients/Events }\end{array}$ \\
\hline $\begin{array}{l}\text { Mok TSK, et } \\
\text { al. 2019 } \\
\text { Keynote-042 }\end{array}$ & $637 / 272$ & $637 / 321$ & \\
\hline $\begin{array}{l}\text { Reck M, et } \\
\text { al. 2016 } \\
\text { Keynote-024 }\end{array}$ & $154 / 115$ & & $151 / 117$ \\
\hline
\end{tabular}

The incidence of death was $48.92 \%$ (387 in 791 patients) in the Pembrolizumab group and 55.58\% in the Chemotherapy group (438 in 788 patients). Pembrolizumab reduced the risk of death by $7 \%$ at 12 months [ARR 7\%; 95\% CI -12\% to $-2 \%$; $\mathrm{p}=0.006 ; \mathrm{I}^{2}=0 \%$, $\mathrm{NNT}=15$ (95\% CI 9 to 56)], Figure 2.

For this comparison, we also evaluated the adverse events due to any cause, degree $\geq 3$, in the population treated (Table 4).

TABLE 4. ADVERSE EVENTS (GRADE $\geq 3$ ) PEMBROLIZUMAB VS. CHEMOTHERAPY.

\begin{tabular}{l|l|l|l} 
Study & $\begin{array}{l}\text { Pembro } \\
\text { Patients/ } \\
\text { Events }\end{array}$ & $\begin{array}{l}\text { Carboplatin + } \\
\text { pemetrexed or } \\
\text { paclitaxel } \\
\text { Patients/Events }\end{array}$ & $\begin{array}{l}\text { * Plati- } \\
\text { num-based } \\
\text { chemotherapy } \\
\text { Patients/Events }\end{array}$ \\
\hline $\begin{array}{l}\text { Mok TSK, et al. } \\
\text { 2019 } \\
\text { Keynote-042 }\end{array}$ & $636 / 113$ & $615 / 252$ & \\
\hline $\begin{array}{l}\text { Reck M, et al. } \\
\text { 2016 } \\
\text { Keynote-024 }\end{array}$ & $154 / 41$ & & $150 / 80$ \\
\hline
\end{tabular}

The incidence of adverse events $\geq 3$ was $19.5 \%$ (154 in 790 patients) in the Pembrolizumab group and $43.4 \%$ in the Chemotherapy group (332 in 765 patients). Pembrolizumab reduced the risk of adverse events by $24 \%$ at 12 months [ARR $=24 \%$; $95 \%$ CI $-28 \%$ to $-19 \%$; $\mathrm{p}<0.00001 ; \mathrm{I}^{2}=0 \%, \mathrm{NNT}=4$ (95\% CI 9 to 5)], Figure 2.

Three primary assays ${ }^{3-5}$ comparing pembrolizumab plus chemotherapy versus chemotherapy allow to combine the results and assess the risk of death in 12 months, as the outcome (Table 5).

In all three studies, patients were randomized (1:1) in blocks of four, stratified by tumor proportion score of PD-L1 ( $<1 \%$ vs. $\geq 1 \%)$.

In the meta-analysis of the results of these three studies, there is a significant difference in the

FIGURE 2. COMPARISON FOREST PLOT: PEMBROLIZUMAB VERSUS CHEMOTHERAPY, OUTCOME: MORTALITY AT 12 MONTHS.

\begin{tabular}{|c|c|c|c|c|c|c|c|c|c|}
\hline \multirow{2}{*}{$\begin{array}{l}\text { Study or Subgroup } \\
\text { Mok TSK } 2019\end{array}$} & \multicolumn{2}{|c|}{ PEMBRO } & $\begin{array}{l}\text { QUIMIOTE } \\
\text { Events }\end{array}$ & $\begin{array}{l}\text { APIA } \\
\text { Total }\end{array}$ & Weight & $\begin{array}{l}\text { Risk Difference } \\
\text { M-H, Fixed, 95\% Cl }\end{array}$ & \multicolumn{3}{|c|}{$\begin{array}{l}\text { Risk Difference } \\
\text { M-H, Fixed, 95\% Cl }\end{array}$} \\
\hline & 113 & 636 & 252 & 615 & $80.4 \%$ & $-0.23[-0.28,-0.18]$ & & \begin{tabular}{|l|l}
- &
\end{tabular} & \\
\hline Reck M 2016 & 41 & 154 & 80 & 150 & $19.6 \%$ & $-0.27[-0.37,-0.16]$ & & & \\
\hline Total (95\% Cl) & & 790 & & 765 & $100.0 \%$ & $-0.24[-0.28,-0.19]$ & & & \\
\hline Total events & 154 & & 332 & & & & & & \\
\hline \multicolumn{7}{|c|}{$\begin{array}{l}\text { Heterogeneity: } \mathrm{Chi}^{2}=0.35, \mathrm{df}=1(P=0.56) ;\left.\right|^{2}=0 \% \\
\text { Test for overall effect: } Z=10.53(P=0.00001)\end{array}$} & $\begin{array}{c}+1 \\
-0.5\end{array}$ & $\begin{array}{c}-0.25 \\
\text { Favours PEMBRO }\end{array}$ & Favours QUIMIOTERAPIA $^{0.25}$ \\
\hline
\end{tabular}


FIGURE 3. COMPARISON FOREST PLOT: PEMBROLIZUMAB VERSUS CHEMOTHERAPY, OUTCOME: ADVERSE EVENTS WITH A DEGREE GREATER THAN OR EQUAL TO 3.

\begin{tabular}{|c|c|c|c|c|c|c|c|c|}
\hline \multirow[b]{2}{*}{ Study or Subgroup } & \multicolumn{2}{|c|}{ PEMBRO } & \multicolumn{2}{|c|}{ CHEMOTHERAPY } & \multirow[b]{2}{*}{ Weight } & \multirow{2}{*}{$\begin{array}{l}\text { Risk Difference } \\
\text { M-H, Fixed, 95\% CI }\end{array}$} & \multirow{2}{*}{\multicolumn{2}{|c|}{$\begin{array}{l}\text { Risk Difference } \\
\text { M-H, Fixed, 95\% Cl }\end{array}$}} \\
\hline & Events & Total & Events & Total & & & & \\
\hline Mok TSK 2019 & 272 & 637 & 321 & 637 & $80.7 \%$ & $-0.08[-0.13,-0.02]$ & -5 & \\
\hline Reck M 2016 & 115 & 154 & 117 & 151 & $19.3 \%$ & $-0.03[-0.12,0.07]$ & & \\
\hline Total (95\% Cl) & & 791 & & 788 & $100.0 \%$ & $-0.07[-0.12,-0.02]$ & & \\
\hline Total events & 387 & & 438 & & & & & \\
\hline \multicolumn{7}{|c|}{ Heterogeneity: $\mathrm{Chi}^{2}=0.77, \mathrm{df}=1(\mathrm{P}=0.38) ; \mathrm{I}^{2}=0 \%$} & $\begin{array}{ll}-0.2 & -0.1 \\
\text { Favours } & \text { PEMBRO }\end{array}$ & $\begin{array}{ccc}0 & 0.1 & 0.2 \\
\text { Favours } & \text { CHEMOTHERAPY }\end{array}$ \\
\hline
\end{tabular}

TABLE 5. MORTALITY - PEMBROLIZUMAB + CHEMOTHERAPY VERSUS CHEMOTHERAPY.

\begin{tabular}{l|l|l|l|l|l|l} 
Study & $\begin{array}{l}\text { Pembro + carbo- } \\
\text { platin + paclitaxel } \\
\text { or nab-paclitaxel } \\
\text { patients/ } \\
\text { events }\end{array}$ & $\begin{array}{l}\text { Pembro + cispla- } \\
\text { tin or carboplatin } \\
\text { + pemetrexed } \\
\text { patients/ } \\
\text { events }\end{array}$ & $\begin{array}{l}\text { Pembro + } \\
\text { carboplatin + } \\
\text { pemetrexed } \\
\text { patients/ } \\
\text { events }\end{array}$ & $\begin{array}{l}\text { Carboplatin + } \\
\text { paclitaxel or } \\
\text { nab-paclitaxel } \\
\text { patients/ } \\
\text { events }\end{array}$ & $\begin{array}{l}\text { Cisplatin or } \\
\text { carboplatin + } \\
\text { pemetrexed } \\
\text { patients/ } \\
\text { events }\end{array}$ & $\begin{array}{l}\text { Carboplatin + } \\
\text { pemetrexede } \\
\text { patients/ } \\
\text { events }\end{array}$ \\
\hline $\begin{array}{l}\text { Paz-Ares L, 2018 } \\
\text { Keynote-407 }\end{array}$ & $278 / 216$ & & $281 / 236$ & $206 / 147$ \\
\hline $\begin{array}{l}\text { Gandhi L, 2018 } \\
\text { Keynote-189 }\end{array}$ & $410 / 247$ & $60 / 27$ & & \\
\hline $\begin{array}{l}\text { Langer CJ, 2016 } \\
\text { Keynote-021 }\end{array}$ & & & & & \\
\hline
\end{tabular}

FIGURE 4. COMPARISON FOREST PLOT: PEMBROLIZUMAB + CHEMOTHERAPY VERSUS CHEMOTHERAPY, OUTCOME: MORTALITY AT 12 MONTHS.

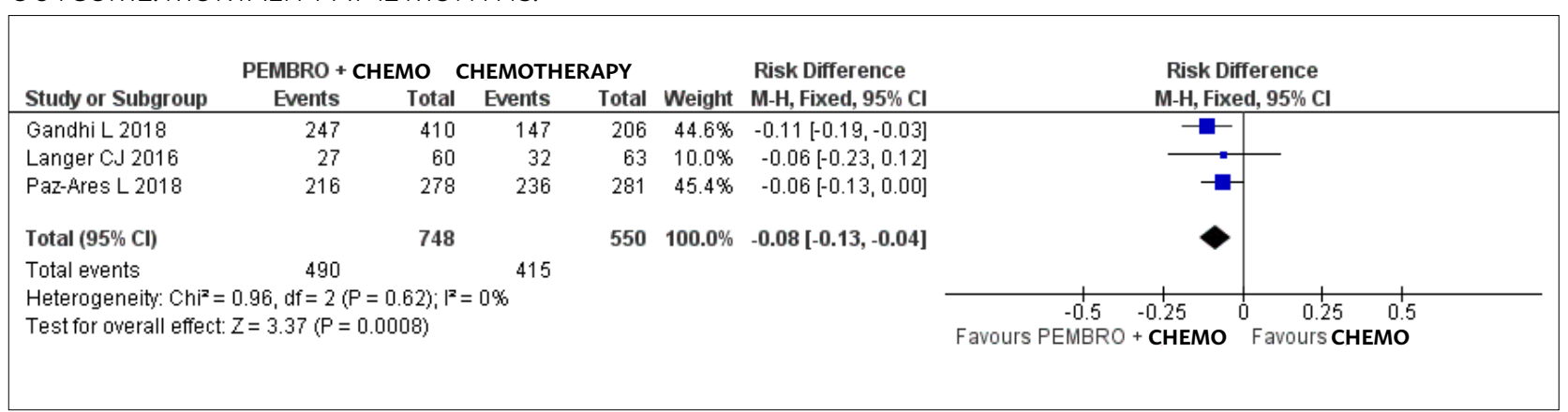

TABLE 6. ADVERSE EVENTS (GRADE $\geq 3$ ) - PEMBROLIZUMAB + CHEMOTHERAPY

\begin{tabular}{|c|c|c|c|c|c|c|}
\hline Study & $\begin{array}{l}\text { Pembro + } \\
\text { carboplatin + } \\
\text { paclitaxel or } \\
\text { nab-paclitaxel } \\
\text { patients/ } \\
\text { events }\end{array}$ & $\begin{array}{l}\text { Pembro }+ \text { cisplatin } \\
\text { or carboplatin }+ \\
\text { pemetrexed } \\
\text { patients/ } \\
\text { events }\end{array}$ & $\begin{array}{l}\text { Pembro }+ \\
\text { carboplatin }+ \\
\text { pemetrexed } \\
\text { patients/ } \\
\text { events }\end{array}$ & $\begin{array}{l}\text { Carboplatin }+ \\
\text { paclitaxel or } \\
\text { nab-paclitaxel } \\
\text { patients/ } \\
\text { events }\end{array}$ & $\begin{array}{l}\text { Cisplatin or } \\
\text { carboplatin + } \\
\text { pemetrexed } \\
\text { patients/ } \\
\text { events }\end{array}$ & $\begin{array}{l}\text { Carboplatin }+ \\
\text { pemetrexede } \\
\text { patients/ } \\
\text { events }\end{array}$ \\
\hline $\begin{array}{l}\text { Paz-Ares L, et al. } 2018 \\
\text { Keynote-407 }\end{array}$ & 278/194 & & & 280/191 & & \\
\hline $\begin{array}{l}\text { Gandhi L, et al. } 2018 \\
\text { Keynote-189 }\end{array}$ & & $405 / 272$ & & & $202 / 133$ & \\
\hline $\begin{array}{l}\text { Langer C), et al. } 2016 \\
\text { Keynote-021 }\end{array}$ & & & $59 / 23$ & & & $62 / 16$ \\
\hline
\end{tabular}

reduction of death, in a 12-month follow-up, of $8 \%(95 \%$ CI -13\% to -4\%); favorable to the treatment with pembrolizumab plus chemotherapy; $\left[\mathrm{I}^{2}=0 \%\right.$; NNT $=12(95 \%$ CI 7 to 25)] - (Figure 4).
These three RCTs analyzed adverse events of any cause, degree $\geq 3$ in the population treated, for comparison between pembrolizumab plus chemotherapy versus chemotherapy (Table 6). 
FIGURE 5. FOREST PLOT COMPARISON: PEMBROLIZUMAB + CHEMOTHERAPY VERSUS CHEMOTHERAPY. RESULTS: ADVERSE EVENTS WITH A DEGREE GREATER THAN OR EQUAL TO 3.

\begin{tabular}{|c|c|c|c|c|c|c|c|c|}
\hline \multirow[b]{2}{*}{ Study or Subgroup } & \multicolumn{2}{|c|}{ PEMBRO + CHEMO } & \multicolumn{2}{|c|}{ CHEMOTHERAPY } & \multirow[b]{2}{*}{ Weight } & \multirow{2}{*}{$\begin{array}{l}\text { Risk Difference } \\
\text { M-H, Fixed, } 95 \% \text { Cl }\end{array}$} & \multirow{2}{*}{\multicolumn{2}{|c|}{$\begin{array}{l}\text { Risk Difference } \\
\text { M-H, Fixed, 95\% Cl }\end{array}$}} \\
\hline & Events & Total & Events & Total & & & & \\
\hline Gandhi L 2018 & 272 & 405 & 133 & 202 & $44.3 \%$ & $0.01[-0.07,0.09]$ & & \\
\hline Langer CJ 2016 & 23 & 59 & 16 & 62 & $9.9 \%$ & $0.13[-0.03,0.30]$ & & \\
\hline Paz-Ares L 2018 & 194 & 278 & 191 & 280 & $45.8 \%$ & $0.02[-0.06,0.09]$ & & \\
\hline Total $(95 \% \mathrm{Cl})$ & & 742 & & 544 & $100.0 \%$ & $0.03[-0.03,0.08]$ & & \\
\hline Total events & 489 & & 340 & & & & & \\
\hline \multicolumn{7}{|c|}{$\begin{array}{l}\text { Heterogeneity: } \mathrm{Chi}^{2}=1.74, \mathrm{df}=2(\mathrm{P}=0.42) ; \mathrm{I}^{2}=0 \% \\
\text { Test for overall effect: } Z=0.98(P=0.33)\end{array}$} & 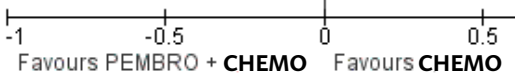 & $-\overrightarrow{1}$ \\
\hline
\end{tabular}

\section{PEMBROLIZUMAB VS CHEMOTHERAPY}

In the meta-analysis of three combined studies, there was no significative difference in adverse events with a degree $\geq 3$, in a 12-month follow-up, between both groups (ARR $=3 \%, 95 \% \mathrm{CI}-0.03$ to 0.08 ; $\mathrm{NNT}=\mathrm{NS}$; $\mathrm{I}^{2}=0 \%$ ) (Figure 5).

\section{SUMMARY OF THE META-ANALYSIS RESULTS}

\section{PEMBROLIZUMAB VERSUS CHEMOTHERAPY}

\begin{tabular}{l|l|l|l|l}
$\begin{array}{l}\text { Result or } \\
\text { Subgroup }\end{array}$ & $\begin{array}{l}\text { Stud- } \\
\text { ies }\end{array}$ & $\begin{array}{l}\text { Partic- } \\
\text { ipants }\end{array}$ & $\begin{array}{l}\text { Statistical } \\
\text { Method }\end{array}$ & $\begin{array}{l}\text { Estimated } \\
\text { effect }\end{array}$ \\
\hline $\begin{array}{l}\text { Mortality in } 12 \\
\text { months }\end{array}$ & $2^{\mathbf{4 . 5}}$ & 1,579 & $\begin{array}{l}\text { Difference } \\
\text { in risk (M-H, } \\
\text { Fixed, 95\% } \\
\text { Cl) }\end{array}$ & $\begin{array}{l}-0.07[-0.12, \\
-0.02]\end{array}$ \\
$\begin{array}{l}\text { Adverse events } \\
\text { with degree } \\
\text { greater than or } \\
\text { equal to 3 }\end{array}$ & $2^{4.5}$ & 1,555 & $\begin{array}{l}\text { Difference } \\
\text { in risk }(\mathrm{M}-\mathrm{H}, \\
\text { Fixed, 95\% } \\
\text { Cl) }\end{array}$ & $\begin{array}{l}-0.24[-0.28, \\
-0.1]\end{array}$ \\
\hline
\end{tabular}

PEMBROLIZUMAB + CHEMOTHERAPY VERSUS CHEMOTHERAPY

\begin{tabular}{l|l|l|l|l}
$\begin{array}{l}\text { Result or } \\
\text { Subgroup }\end{array}$ & $\begin{array}{l}\text { Stud- } \\
\text { ies }\end{array}$ & $\begin{array}{l}\text { Partic- } \\
\text { ipants }\end{array}$ & $\begin{array}{l}\text { Statistical } \\
\text { Method }\end{array}$ & $\begin{array}{l}\text { Estimated } \\
\text { effect }\end{array}$ \\
\hline $\begin{array}{l}\text { Mortality in 12 } \\
\text { months }\end{array}$ & $3^{6-8}$ & 1,298 & $\begin{array}{l}\text { Difference } \\
\text { in risk }(\mathrm{M}-\mathrm{H}, \\
\text { Fixed, 95\% Cl) }\end{array}$ & $\begin{array}{l}-0.08[-0.13, \\
-0.04] \\
\mathrm{NNT} \mathrm{12,} \\
95 \% \mathrm{Cl} 7 \\
\text { to 25 }\end{array}$ \\
\hline $\begin{array}{l}\text { Adverse events } \\
\text { with a degree } \\
\text { greater than or } \\
\text { equal to 3 }\end{array}$ & $3^{\mathbf{6 - 8}}$ & 1,286 & $\begin{array}{l}\text { Difference } \\
\text { in risk }(\mathrm{M}-\mathrm{H}, \\
\text { Fixed, 95\% Cl) }\end{array}$ & $\begin{array}{l}0.03[-0.03, \\
0.08]\end{array}$ \\
\hline
\end{tabular}

\section{QUALITY OF EVIDENCE FOR THE DEATH OUTCOME}

\section{Pembrolizumab versus Chemotherapy}

Question: Mortality with the use of pembrolizumab compared to chemotherapy for locally advanced or metastatic NSCLC.

TABLE 7. ANALYSIS OF THE QUALITY OF EVIDENCE (GRADE PRO SOFTWARE)6

\begin{tabular}{|c|c|c|c|c|c|c|c|c|c|c|c|c|}
\hline \multicolumn{7}{|c|}{ Evaluation of certainty } & \multicolumn{2}{|c|}{ No of patients } & \multicolumn{2}{|l|}{ Effect } & \multirow{2}{*}{$\begin{array}{l}\text { Certain- } \\
\text { ty }\end{array}$} & \multirow{2}{*}{$\begin{array}{l}\text { Impor- } \\
\text { tance }\end{array}$} \\
\hline $\begin{array}{l}\text { No of } \\
\text { studies }\end{array}$ & $\begin{array}{l}\text { Design } \\
\text { of the } \\
\text { study }\end{array}$ & $\begin{array}{l}\text { Risk of } \\
\text { bias }\end{array}$ & $\begin{array}{l}\text { Incon- } \\
\text { sistency }\end{array}$ & $\begin{array}{l}\text { Indirect } \\
\text { evi- } \\
\text { dence }\end{array}$ & $\begin{array}{l}\text { Impre- } \\
\text { cision }\end{array}$ & $\begin{array}{l}\text { Other } \\
\text { consid- } \\
\text { erations }\end{array}$ & $\begin{array}{l}\text { Pem- } \\
\text { broli- } \\
\text { zumab }\end{array}$ & $\begin{array}{l}\text { Chemo- } \\
\text { therapy }\end{array}$ & $\begin{array}{l}\text { Relative } \\
(95 \% \\
\mathrm{Cl})\end{array}$ & $\begin{array}{l}\text { Absolute } \\
(95 \% \mathrm{Cl})\end{array}$ & & \\
\hline \multicolumn{13}{|c|}{ Mortality in 12 months (follow-up: variation of 30 days to 12 months; assessed with: number of deaths in the intervention and control) } \\
\hline 2 & $\begin{array}{l}\text { ran- } \\
\text { domized } \\
\text { clinical } \\
\text { trials }\end{array}$ & $\begin{array}{l}\text { not } \\
\text { severe }\end{array}$ & $\begin{array}{l}\text { not } \\
\text { severe }\end{array}$ & $\begin{array}{l}\text { not } \\
\text { severe }\end{array}$ & $\begin{array}{l}\text { not } \\
\text { severe }\end{array}$ & None & $\begin{array}{l}387 / 791 \\
(48.9 \%)\end{array}$ & $\begin{array}{l}438 / 788 \\
(55.6 \%)\end{array}$ & $\begin{array}{l}\text { RR } 0.88 \\
(0.80 \text { to } \\
0.96)\end{array}$ & $\begin{array}{l}\text { minus } 7 \\
\text { per } 100 \\
\text { (from } \\
\text { minus } 11 \\
\text { to minus } \\
\text { 2) }\end{array}$ & $\begin{array}{l}\oplus \oplus \\
\oplus \oplus \\
\mathrm{HIGH}\end{array}$ & $\begin{array}{l}\text { IM- } \\
\text { PORT- } \\
\text { ANT }\end{array}$ \\
\hline
\end{tabular}

$\mathrm{Cl}$ : Confidence interval; RR: Relative Risk

\section{Pembrolizumab + Chemotherapy versus Chemotherapy}

Question: Pembrolizumab + Chemotherapy compared to chemotherapy for locally advanced or metastatic NSCLC. 
TABLE 8. ANALYSIS OF THE QUALITY OF EVIDENCE (GRADE PRO SOFTWARE) ${ }^{6}$

\begin{tabular}{|c|c|c|c|c|c|c|c|c|c|c|c|c|c|}
\hline \multicolumn{7}{|c|}{ Evaluation of certainty } & \multicolumn{2}{|c|}{ No of patients } & \multicolumn{3}{|l|}{ Effect } & \multirow{2}{*}{$\begin{array}{l}\text { Cer- } \\
\text { tainty }\end{array}$} & \multirow{2}{*}{$\begin{array}{l}\text { Impor- } \\
\text { tance }\end{array}$} \\
\hline $\begin{array}{l}\mathrm{N}^{\circ} \text { of } \\
\text { studies }\end{array}$ & $\begin{array}{l}\text { Design } \\
\text { of the } \\
\text { study }\end{array}$ & $\begin{array}{l}\text { Risk } \\
\text { of } \\
\text { bias }\end{array}$ & $\begin{array}{l}\text { In- } \\
\text { con- } \\
\text { sis- } \\
\text { tence }\end{array}$ & $\begin{array}{l}\text { Indirect } \\
\text { evi- } \\
\text { dence }\end{array}$ & $\begin{array}{l}\text { Im- } \\
\text { preci- } \\
\text { sion }\end{array}$ & $\begin{array}{l}\text { Other } \\
\text { con- } \\
\text { sider- } \\
\text { ations }\end{array}$ & $\begin{array}{l}\text { Pem- } \\
\text { broli- } \\
\text { zumab+ } \\
\text { Chemo- } \\
\text { therapy }\end{array}$ & $\begin{array}{l}\text { Chemo- } \\
\text { therapy }\end{array}$ & $\begin{array}{l}\text { Rela- } \\
\text { tive } \\
(95 \% \\
\mathrm{Cl})\end{array}$ & $\begin{array}{l}\text { Absolute } \\
(95 \% \mathrm{Cl})\end{array}$ & & & \\
\hline \multicolumn{14}{|c|}{ Mortality in 12 months (follow-up: variation of 30 days to 12 months; assessed with: number of deaths in the intervention and control) } \\
\hline 3 & $\begin{array}{l}\text { ran- } \\
\text { dom- } \\
\text { ized } \\
\text { clinical } \\
\text { trials }\end{array}$ & $\begin{array}{l}\text { not } \\
\text { severe }\end{array}$ & $\begin{array}{l}\text { not } \\
\text { severe }\end{array}$ & $\begin{array}{l}\text { not } \\
\text { severe }\end{array}$ & $\begin{array}{l}\text { not } \\
\text { severe }\end{array}$ & None & $\begin{array}{l}490 / 748 \\
(65.5 \%)\end{array}$ & $\begin{array}{l}415 / 550 \\
(75.5 \%)\end{array}$ & $\begin{array}{l}\text { RR } 0.89 \\
(0.83 \text { to } \\
0.95)\end{array}$ & $\begin{array}{l}\text { minus } \\
8 \text { per } \\
100 \\
\text { (from } \\
\text { minus } \\
13 \text { to } \\
\text { minus } \\
4 \text { ) }\end{array}$ & $\begin{array}{l}\oplus \oplus \oplus \oplus \\
\mathrm{HIGH}\end{array}$ & & $\begin{array}{l}\text { IMPORT- } \\
\text { ANT }\end{array}$ \\
\hline
\end{tabular}

Cl: Confidence interval; RR: Relative Risk.

\section{SYNTHESIS OF EVIDENCE}

In adult patients with squamous or non-squamous NSCLC, locally advanced or metastatic, without previous systemic therapy, without mutations in the EGFR gene and gene rearrangement of the ALK, with a score of 0 or 1 in the Ecog performance scale, with at least one measurable lesion evaluated by Recist version 1.1, the treatment with pembrolizumab, associated or not to chemotherapy, compared with standard chemotherapy reduces the risk of death in 12 months by $7 \%$ and $8 \%$, respectively. The quality of the evidence that supports this result is high.

For these patients, pembrolizumab reduced adverse events of degree $\geq 3$ by $24 \%$ in comparison with chemotherapy, and when associated with it, it showed no difference in adverse events of degree $\geq 3$ in comparison with chemotherapy alone, in up to 12 months. The quality of the evidence that supports this result is high.

\section{RECOMMENDATION}

The treatment with Pembrolizumab, associated or not with chemotherapy, in adult patients with squamous or non-squamous NSCLC, locally advanced or metastatic, without previous systemic therapy, without mutations in the EGFR gene and gene rearrangement of the ALK, with a score of 0 or 1 in the Ecog performance scale, with at least one measurable lesion evaluated by Recist version 1.1, and PD-L1 expression [Tumor Proportion Score (TPS)] $\geq 1 \%$ (positive PDL-1). High quality of evidence.

\section{DISCUSSION}

Among human neoplasms for which the investigation of PD-L1 immunohistochemical expression is validated by clinical studies, with an undeniable predictive value of the response to anti-PD-1 therapies available, the non-small cell lung carcinomas stand out. The PD-L1 expression on the tumor-cell membrane is indicated as an aid in the identification of patients for treatment with pembrolizumab. The result of the PD-L1 expression is determined by the percentage of tumor cells with membrane immunostaining (full or basolateral) of any intensity and/or by the percentage of immune cells associated with the tumor with immunostaining of any intensity, according to the type of neoplasia under analysis. Patients with a tumor proportion score (TPS) $<1 \%$ of the PD-L1 biomarker in the tumor tissue are considered PD-L1 negative and with TPS $\geq 1 \%$ positive.

In the comparison pembrolizumab versus chemotherapy, we included two studies ${ }^{1.7}$ that included only patients with TPS $\geq 1 \%$ (PDL-1 positive). However, in the comparison of pembrolizumab plus chemotherapy versus chemotherapy alone, the three studies assessed $^{3-5}$ included patients with TPS $<1 \%$ (PDL-1 negative) and TPS $\geq 1 \%$ ( $1-49 \%$ and $\geq 50 \%$ ), uniformly distributed between the groups, with an analysis of these subgroups.

It should be emphasized, however, that the greater the number of subgroups analyzed in one sample, the higher the probability of false-positive results; it is also added to that limitation the frequent tendency of 
reporting, after various analyses, only the significant results, which can potentially distort the interpretation of the results. In the event of a positive result, is there effectively a significant difference in the treatment effect, or it is mere occurrence at random (considering the absence of a prior determination of sampling and subsequent statistical power for such difference) $)^{3}$ ?

Considering that: there is a lack of RCTs with a prior determination of sampling comparing positive and negative PDL-1 patients, and the mechanism of action of pembrolizumab in patients with NSCLC.

\section{ANNEX I}

The purpose of this assessment is to identify the benefits of immunotherapy with pembrolizumab, associated or not with chemotherapy, in the treatment of patients with locally advanced or metastatic NSCLC, without mutations of the EGFR gene or gene rearrangement of the ALK, with PD-L1 gene expression, in comparison to chemotherapy alone (current standard treatment).

\section{Clinical question}

What is the impact of pembrolizumab, associated or not to chemotherapy, on the outcomes of overall mortality (death from any cause) and adverse events in the treatment of patients with advanced NSCLC when compared to chemotherapy alone?

\section{Structured question}

Patient - Adult patients with advanced NSCLC;

Intervention - Treatment with Pembrolizumab alone or combined with chemotherapy;

Comparison - Chemotherapy, except monochemotherapy with docetaxel;

Outcomes - Death (due to any cause) and adverse events.

\section{Eligibility criteria}

Excluded the outcomes - quality of life, objective response, survival free of progression - analyses of tumor proportion score (TPS) of the PD-L1 biomarker on the tumor tissue were not evaluated.

Randomized clinical trial.

Without time or language restrictions.

Full text available for access.

\section{Search strategies used}

The search for evidence will be conducted on Medline virtual scientific information database, using the following search strategy:

(((()Pulmonary Neoplasms OR Lung Neoplasm OR Pulmonary Neoplasm OR Lung Neoplasms OR Lung Cancers OR Lung Cancer OR Lung Neoplasm OR Lung Neoplasms OR PD-L1))) AND ((pembrolizumab) AND Random* $)))$ OR ((((Pulmonary Neoplasms OR Lung Neoplasm OR Pulmonary Neoplasm OR Lung Neoplasms OR Lung Cancers OR Lung Cancer OR Lung Neoplasm OR Lung Neoplasms))) AND ((pembrolizumab OR PD-L1) AND Random*)).

In the Central/Cochrane databases, the search strategy will be: (Lung Neoplasm OR Pulmonary Neoplasm OR Lung Cancer) AND pembrolizumab.

\section{Extraction of results}

We will extract the following data from the studies: name of the author and year of publication, study population, intervention and comparison methods, the absolute number of deaths and adverse events, time of follow-up.

Randomized clinical trials will have their risk of biases analyzed according to the following criteria: randomization, blinded allocation, double-blinding, losses, prognostic characteristics, presence of relevant outcome, time for the outcome, method for outcome measurement, sample size calculation, early interruption, presence of other biases.

The results will be presented as the difference in the risk of death or adverse events between pembrolizumab therapy alone or in combination with chemotherapy, and the treatment with chemotherapy alone. The confidence level adopted was $95 \%$.

The results of the studies included will be combined and meta-analyzed by RevMan $5.3^{8}$, and the difference in overall risk will be the final measure used to support the synthesis of evidence that will answer the clinical question of this review.

Furthermore, the quality of evidence will be graded as high, moderate, low, or very low using the Grade instrument ${ }^{6}$ and taking into account the risk of bias, the presence of inconsistency, vagueness or indirect evidence in the meta-analysis of the outcomes of death and adverse events, and the presence of publication bias. Table 5. Quality of evidence (GRADE).

Explanation: a. 50\% with randomization inadequate or not described; only one with blinded 
TABLE 5. QUALITY OF EVIDENCE (GRADE).

\begin{tabular}{|c|c|c|c|c|c|c|c|c|c|c|c|c|}
\hline \multicolumn{7}{|c|}{ Evaluation of certainty } & \multicolumn{2}{|c|}{$\mathrm{N}^{\mathrm{O}}$ of patients } & \multicolumn{2}{|l|}{ Effect } & \multirow[t]{2}{*}{ Certainty } & \multirow{2}{*}{$\begin{array}{l}\text { Impor- } \\
\text { tance }\end{array}$} \\
\hline $\begin{array}{l}\text { No of } \\
\text { stud- } \\
\text { ies }\end{array}$ & $\begin{array}{l}\text { Design } \\
\text { of the } \\
\text { study }\end{array}$ & $\begin{array}{l}\text { Risk of } \\
\text { bias }\end{array}$ & $\begin{array}{l}\text { Incon- } \\
\text { sisten- } \\
\text { cy }\end{array}$ & $\begin{array}{l}\text { Indi- } \\
\text { rect } \\
\text { evi- } \\
\text { dence }\end{array}$ & $\begin{array}{l}\text { Impre- } \\
\text { cision }\end{array}$ & $\begin{array}{l}\text { Other } \\
\text { consid- } \\
\text { erations }\end{array}$ & $\begin{array}{l}\text { Levosi- } \\
\text { mendan }\end{array}$ & $\begin{array}{l}\text { Dobu- } \\
\text { tamine }\end{array}$ & $\begin{array}{l}\text { Relative } \\
(95 \% \\
\mathrm{Cl})\end{array}$ & $\begin{array}{l}\text { Absolute } \\
(95 \% \mathrm{Cl})\end{array}$ & & \\
\hline \multicolumn{13}{|c|}{ Mortality at 24 hours (assessed with: Number of deaths in 24 hours) } \\
\hline 4 & $\begin{array}{l}\text { ran- } \\
\text { domized } \\
\text { clinical } \\
\text { trials }\end{array}$ & severe ${ }^{\text {a }}$ & $\begin{array}{l}\text { not } \\
\text { severe }\end{array}$ & $\begin{array}{l}\text { not } \\
\text { severe }\end{array}$ & $\begin{array}{l}\text { not } \\
\text { severe }^{\text {b }}\end{array}$ & none & $\begin{array}{l}1 / 208 \\
(0.5 \%)\end{array}$ & $\begin{array}{l}4 / 204 \\
(2.0 \%)\end{array}$ & $\begin{array}{l}\text { RR } 3.05 \\
(0.49 \text { to } \\
18.90)\end{array}$ & $\begin{array}{l}40 \text { more } \\
\text { per } 1,000 \\
\text { (from } \\
\text { minus } 10 \text { to } \\
351 \text { more) }\end{array}$ & $\begin{array}{l}\oplus \oplus \oplus \bigcirc \\
\text { MODER- } \\
\text { ATE }\end{array}$ & $\begin{array}{l}\text { IM- } \\
\text { PORT- } \\
\text { ANT }\end{array}$ \\
\hline \multicolumn{13}{|c|}{ Mortality at 30 days (assessed with: Number of deaths up to 30 days) } \\
\hline 3 & $\begin{array}{l}\text { ran- } \\
\text { domized } \\
\text { clinical } \\
\text { trials }\end{array}$ & $\begin{array}{l}\text { not } \\
\text { severe }\end{array}$ & severe $^{c}$ & $\begin{array}{l}\text { not } \\
\text { severe }\end{array}$ & severe $^{d}$ & none & $\begin{array}{l}93 / 836 \\
(11.1 \%)\end{array}$ & $\begin{array}{l}125 / 831 \\
(15.0 \%)\end{array}$ & $\begin{array}{l}\text { RR } 1.74 \\
\text { (0.94 to } \\
3.19)\end{array}$ & $\begin{array}{l}111 \text { more } \\
\text { per } 1,000 \\
\text { (from } \\
\text { minus } 9 \text { to } \\
329 \text { more) } \\
\end{array}$ & $\begin{array}{l}\oplus \oplus \bigcirc \bigcirc \\
\text { LOW }\end{array}$ & $\begin{array}{l}\text { IM- } \\
\text { PORT- } \\
\text { ANT }\end{array}$ \\
\hline \multicolumn{13}{|c|}{ Mortality between 120 and 180 days (follow-up: variation 120 days to 180 days; assessed with: Number of deaths in this period) } \\
\hline 4 & $\begin{array}{l}\text { ran- } \\
\text { domized } \\
\text { clinical } \\
\text { trials }\end{array}$ & severe $^{\mathbf{e}}$ & $\begin{array}{l}\text { not } \\
\text { severe }\end{array}$ & $\begin{array}{l}\text { not } \\
\text { severe }\end{array}$ & severe $^{f}$ & none & $\begin{array}{l}206 / 811 \\
(25.4 \%)\end{array}$ & $\begin{array}{l}236 / 807 \\
(29.2 \%)\end{array}$ & $\begin{array}{l}\text { RR } 1.15 \\
(0.98 \text { to } \\
1.35)\end{array}$ & $\begin{array}{l}44 \text { more per } \\
1,000 \\
\text { (from } \\
\text { minus } 6 \text { to } \\
102 \text { more) }\end{array}$ & $\begin{array}{l}\oplus \oplus \bigcirc \bigcirc \\
\text { LOW }\end{array}$ & $\begin{array}{l}\text { IM- } \\
\text { PORT- } \\
\text { ANT }\end{array}$ \\
\hline
\end{tabular}

allocation, three studies without blinding; only with sample size calculation; b. The overall result does not exclude the benefit or harm; c. Test for inconsistency I2 equal to 70\%; small overlap of confidence intervals; $d$. The result does not exclude great harm or benefit; e. 2 studies with Jadad = 1 and 2 studies with Jadad $>=3$; $f$. The result does not exclude great harm or benefit

\section{Critical evaluation and level of evidence}

All evidence retrieved was evaluated according to their risk of bias (level of error estimated and inherent in the delineation of research or study design used).

For the evaluation of the risk of bias of the RCTs, the following items were considered: if the issue was focal, appropriate randomization, blinded allocation, double-blind, losses $(>20 \%)$, prognostic characteristics, outcomes (time, adequacy, measurement), analysis by intention to treat (ITT), sample size calculation, Jadad scale ${ }^{7}$.

Reflecting the level of uncertainty of the results (effects of benefit or harm), the strength of the evidence can be very low, low, moderate, or strong, depending on:

1. The risks of bias of each individual and meta-analyzed study.
2. The magnitude and accuracy of the results for each outcome analyzed.

3. The relevance, applicability, and generalization of these results.

\section{Presentation of the results}

In the search for evidence, we retrieved 244 papers, selecting by title and abstract nine studies of immunotherapy with pembrolizumab, associated or not to chemotherapy, in the treatment of patients with NSCLC, compared with chemotherapy alone, of which six studies were accessed since they met the eligibility criteria for analysis of the full text. Of the six studies, five were selected to support this assessment ${ }^{1-5}$; the grounds for exclusion and the list of studies excluded are available in the references, Figure 6 and Table 9 in the Annexes.

NSCLC $=$ Non-small-cell lung carcinoma; CNS $=$ Central nervous system; AUC = Area under the concentration-time curve; OS = overall survival; SFP = Survival free of progression; PD-L1 = Programmed death ligand 1; TPS = Tumor proportion score of biomarker PD-L1 in tumor tissue; EGFR = Epidermal growth factor receptor; ALK = Anaplastic Lymphoma Kinase; Ecog = Eastern Cooperative Oncology Group; Recist $=$ Response Evaluation Criteria in solid tumors. 
TABLE 2. DESCRIPTION OF THE BIASES IN THE STUDIES INCLUDED

\begin{tabular}{|c|c|c|c|c|c|c|c|c|c|}
\hline Study and year & Random & $\begin{array}{l}\text { Blinded } \\
\text { allocation }\end{array}$ & $\begin{array}{l}\text { Dou- } \\
\text { ble-blind }\end{array}$ & Losses & $\begin{array}{l}\text { Charac- } \\
\text { teristics } \\
\text { Prognosis }\end{array}$ & $\begin{array}{l}\text { Out- } \\
\text { comes }\end{array}$ & $\begin{array}{l}\text { Analysis } \\
\text { per ITT }\end{array}$ & $\begin{array}{l}\text { Sample } \\
\text { size cal- } \\
\text { culation }\end{array}$ & Jadad $^{7}$ \\
\hline Mok TSK 2019 & & & & & & & & & 4 \\
\hline Reck M 2016 & & & & & & & & & 4 \\
\hline Gandhi L 2018 & & & & & & & & & 5 \\
\hline Paz-Ares L 2018 & & & & & & & & & 5 \\
\hline Langer CJ 2016 & & & & & & & & & 4 \\
\hline
\end{tabular}

ITT = intention-to-treat analysis $\square$ Low risk of bias the $\square$ Presence of bias $\square$ Unclear risk of bias

TABLE 1. DESCRIPTION OF THE STUDIES INCLUDED

\begin{tabular}{|c|c|c|c|c|c|}
\hline STUDY & Population & Intervention & Comparison & $\begin{array}{l}\text { Out- } \\
\text { comes }\end{array}$ & $\begin{array}{l}\text { Time } \\
\text { (median, } \\
\text { months) }\end{array}$ \\
\hline $\begin{array}{l}\text { Mok TSK, et } \\
\text { al. } 2019 \\
\text { Keynote-042 }\end{array}$ & $\begin{array}{l}\geq 18 \text { years) with locally advanced or } \\
\text { metastatic NSCLC, not previously treated, } \\
\text { without EGFR mutation or ALK transloca- } \\
\text { tion, and with a score of O or } 1 \text { in the Ecog } \\
\text { performance scale, life expectancy of three } \\
\text { months or more, and a PD-L1TPS of } 1 \% \text { or } \\
\text { greater. } \\
\text { Excluded if: unstable or untreated CNS } \\
\text { metastases, a history of noninfectious } \\
\text { pneumonitis requiring systemic glucocorti- } \\
\text { coids, active autoimmune disease, systemic } \\
\text { immunosuppressive treatment, or active } \\
\text { infection by the virus of hepatitis B or C. }\end{array}$ & $\begin{array}{l}\text { Pembrolizumab } 200 \\
\text { mg every three weeks, } \\
\text { in up to } 35 \text { cycles }\end{array}$ & $\begin{array}{l}\text { Carboplatin to achieve an AUC } \\
\text { of } 5-6 \mathrm{mg} / \mathrm{mL} \text { per minute } \\
\text { plus paclitaxel } 200 \mathrm{mg} / \mathrm{m}^{2} \text { or } \\
\text { pemetrexed } 500 \mathrm{mg} / \mathrm{m}^{2}\end{array}$ & $\begin{array}{l}\text { OS } \\
\text { SFP } \\
\text { Adverse } \\
\text { events }\end{array}$ & 12.8 \\
\hline $\begin{array}{l}\text { Reck M, et al. } \\
2016 \\
\text { Keynote-024 }\end{array}$ & $\begin{array}{l}\geq 18 \text { years, NSCLC histologically or cytolog- } \\
\text { ically confirmed in stage IV, without EGFR } \\
\text { mutations or ALKtranslocation, without pri- } \\
\text { or systemic therapy for metastatic disease, } \\
\text { with a } 0 \text { or } 1 \text { score in the ECOG perfor- } \\
\text { mance status, at least one measurable lesion } \\
\text { according to Recist version 1.1, life expectan- } \\
\text { cy of at least three months, and a 50\% or } \\
\text { more score of PD-L1 tumor proportion. } \\
\text { Excluded if: receiving systemic gluco- } \\
\text { corticoids (excluding daily replacement } \\
\text { therapy with glucocorticoids for conditions } \\
\text { such as pituitary or adrenal insufficiency) } \\
\text { or other immunosuppressive treatment, } \\
\text { with untreated brain metastases, active } \\
\text { autoimmune disease for which they } \\
\text { received systemic treatment over the past } \\
\text { two years, active interstitial lung disease or } \\
\text { pneumonitis history for which they received } \\
\text { glucocorticoids. }\end{array}$ & $\begin{array}{l}\text { Pembrolizumab in a } \\
\text { fixed dose of } 200 \text { mg } \\
\text { every three weeks. }\end{array}$ & $\begin{array}{l}\text { Platinum-based chemo- } \\
\text { therapy to the choice of the } \\
\text { researcher during } 4 \text { to } 6 \text { cycles: } \\
\text { carboplatin plus pemetrexed, } \\
\text { cisplatin plus pemetrexed, } \\
\text { carboplatin plus gemcitabine, } \\
\text { cisplatin plus gemcitabine, } \\
\text { cisplatin plus gemcitabine or } \\
\text { carboplatin plus paclitaxel. } \\
\text { The chemotherapy regimens } \\
\text { that included pemetrexed } \\
\text { were allowed only for patients } \\
\text { who had non-squamous } \\
\text { tumors. } \\
\text { Crossover allowed. }\end{array}$ & $\begin{array}{l}\text { OS } \\
\text { SFP } \\
\text { Adverse } \\
\text { events }\end{array}$ & 25.2 \\
\hline $\begin{array}{l}\text { Gandhi L et al. } \\
2018 \\
\text { Keynote-189 }\end{array}$ & $\begin{array}{l}\geq 18 \text { years, metastatic NSCLC, non-squa- } \\
\text { mous, without mutations in the EGFR } \\
\text { gene and ALK rearrangement, without prior } \\
\text { therapy for the disease. } \\
\text { Other conditions: an ECOG performance } \\
\text { status of O or 1; at least one measurable } \\
\text { lesion according to Recist version 1.1, and } \\
\text { provide a sample of the tumor for determin- } \\
\text { ing the PD-L1state. } \\
\text { Excluded if: symptomatic CNS metastases, } \\
\text { history of non-infectious pneumonitis re- } \\
\text { quiring the use of glucocorticoids, autoim- } \\
\text { mune disease with systemic therapy in the } \\
\text { past two years, medical condition requiring } \\
\text { immunosuppression, received more than } 30 \\
\text { Gy of radiotherapy to the chest over the past } \\
\text { six months. }\end{array}$ & $\begin{array}{l}\text { Pemetrexed ( } 500 \\
\mathrm{mg} / \mathrm{m}^{2} \mathrm{IV} \text { ) and a } \\
\text { platinum-based drug } \\
\text { at the choice of the } \\
\text { investigator (cisplatin } \\
75 \mathrm{mg} / \mathrm{m}^{2} \text { of body } \\
\text { surface or carboplatin } \\
\text { AUC } 5 \mathrm{mg} / \mathrm{mL} / \mathrm{min} \\
\text { intravenously) plus } \\
200 \mathrm{mg} \text { of pembroli- } \\
\text { zumab every three } \\
\text { weeks, for four cycles, } \\
\text { followed by pembroli- } \\
\text { zumab until a total of } \\
35 \text { cycles, plus mainte- } \\
\text { nance therapy with } \\
\text { pemetrexed. }\end{array}$ & $\begin{array}{l}\text { Pemetrexed ( } 500 \mathrm{mg} / \mathrm{m}^{2} \mathrm{IV} \text { ) } \\
\text { and a platinum-based drug at } \\
\text { the choice of the investigator } \\
\text { (cisplatin } 75 \mathrm{mg} / \mathrm{m}^{2} \text { of body } \\
\text { surface or carboplatin AUC } \\
5 \mathrm{mg} / \mathrm{mL} / \mathrm{min} \text { intravenous) } \\
\text { plus a placebo every three } \\
\text { weeks, for four cycles, fol- } \\
\text { lowed by a placebo until a total } \\
\text { of } 35 \text { cycles, plus maintenance } \\
\text { therapy with pemetrexed. }\end{array}$ & $\begin{array}{l}\text { OS } \\
\text { SFP. } \\
\text { Adverse } \\
\text { events }\end{array}$ & 10.5 \\
\hline
\end{tabular}




\begin{tabular}{|c|c|c|c|c|c|}
\hline STUDY & Population & Intervention & Comparison & $\begin{array}{l}\text { Out- } \\
\text { comes }\end{array}$ & $\begin{array}{l}\text { Time } \\
\text { (median, } \\
\text { months) }\end{array}$ \\
\hline $\begin{array}{l}\text { Paz-Ares L et } \\
\text { al. } 2018 \\
\text { Keynote-407 }\end{array}$ & $\begin{array}{l}\geq 18 \text { years; squamous NSCLC stage IV, with- } \\
\text { out prior systemic therapy for metastatic } \\
\text { disease, ECOG performance status score of } \\
0 \text { or 1, with at least one measurable lesion } \\
\text { according to Recist version 1.1, provided a } \\
\text { tumor sample for determining the PD-L1 } \\
\text { state. } \\
\text { Excluded if: symptomatic metastases of the } \\
\text { CNS, history of non-infectious pneumonitis } \\
\text { that required the use of glucocorticoids; } \\
\text { autoimmune disease that required systemic } \\
\text { therapy in the past two years; medical con- } \\
\text { dition requiring immunosuppression. }\end{array}$ & $\begin{array}{l}\text { Pembrolizumab } 200 \\
\text { mg for up to } 35 \text { cycles } \\
\text { + carboplatin and } \\
\text { paclitaxel or nanopar- } \\
\text { ticle albumin-bound } \\
\text { [NAB] - paclitaxel for } \\
\text { the first four cycles. }\end{array}$ & $\begin{array}{l}\text { Saline (placebo) for up to } 35 \\
\text { cycles + carboplatin and pacl- } \\
\text { itaxel or nanopartícula albu- } \\
\text { min-bound [NAB] - paclitaxel } \\
\text { during the first four cycles. }\end{array}$ & $\begin{array}{l}\text { SFP } \\
\text { OS } \\
\text { Adverse } \\
\text { events }\end{array}$ & 7.8 \\
\hline $\begin{array}{l}\text { Langer C et et } \\
\text { al. } 2016 \\
\text { Keynote-021 }\end{array}$ & $\begin{array}{l}\text { No previous systemic treatment for } \\
\text { non-squamous NSCLC, cytologically or his- } \\
\text { tologically confirmed, Stage IIIB or IV, and } \\
\text { absence of EGFR target mutations or ALK } \\
\text { translocations; ECOG performance status of } \\
\text { O or 1, at least one measurable lesion eval- } \\
\text { uated by Recist version 1.1, life expectancy } \\
\text { of three months or more, and supply of a } \\
\text { sample of the tumor for evaluation of the } \\
\text { PD-L1expression. } \\
\text { Excluded if: received more than } 30 \text { Gy } \\
\text { of radiation to the lungs in the previous } \\
\text { six months; continuous use of systemic } \\
\text { corticosteroids or other immunosuppressive } \\
\text { treatment, active autoimmune disease that } \\
\text { required systemic treatment in the past } \\
\text { two years (excluding replacement therapy), } \\
\text { untreated brain metastases (allowed treated, } \\
\text { stable metastasis), or active interstitial lung } \\
\text { disease, history of pneumonitis requiring } \\
\text { intravenous glucocorticoids. }\end{array}$ & $\begin{array}{l}\text { Pembrolizumab } 200 \\
\text { mg + carboplatin } \\
\text { AUC } 5 \mathrm{mg} / \mathrm{mL} / \mathrm{min} \\
\text { and pemetrexed } \\
\text { intravenous } 500 \mathrm{mg} / \\
\mathrm{m}^{2} \text { every three weeks } \\
\text { followed by pembroli- } \\
\text { zumab for } 24 \text { months } \\
\text { and maintenance } \\
\text { therapy with unde- } \\
\text { fined pemetrexed. }\end{array}$ & $\begin{array}{l}\text { Four cycles of carboplatin } \\
\text { and pemetrexed, followed by } \\
\text { maintenance therapy with } \\
\text { undefined pemetrexed. }\end{array}$ & $\begin{array}{l}\text { Ob- } \\
\text { jective } \\
\text { Response } \\
\text { SFP } \\
\text { OS } \\
\text { Adverse } \\
\text { events }\end{array}$ & 23.9 \\
\hline
\end{tabular}

FIGURE 6. FLOWCHART

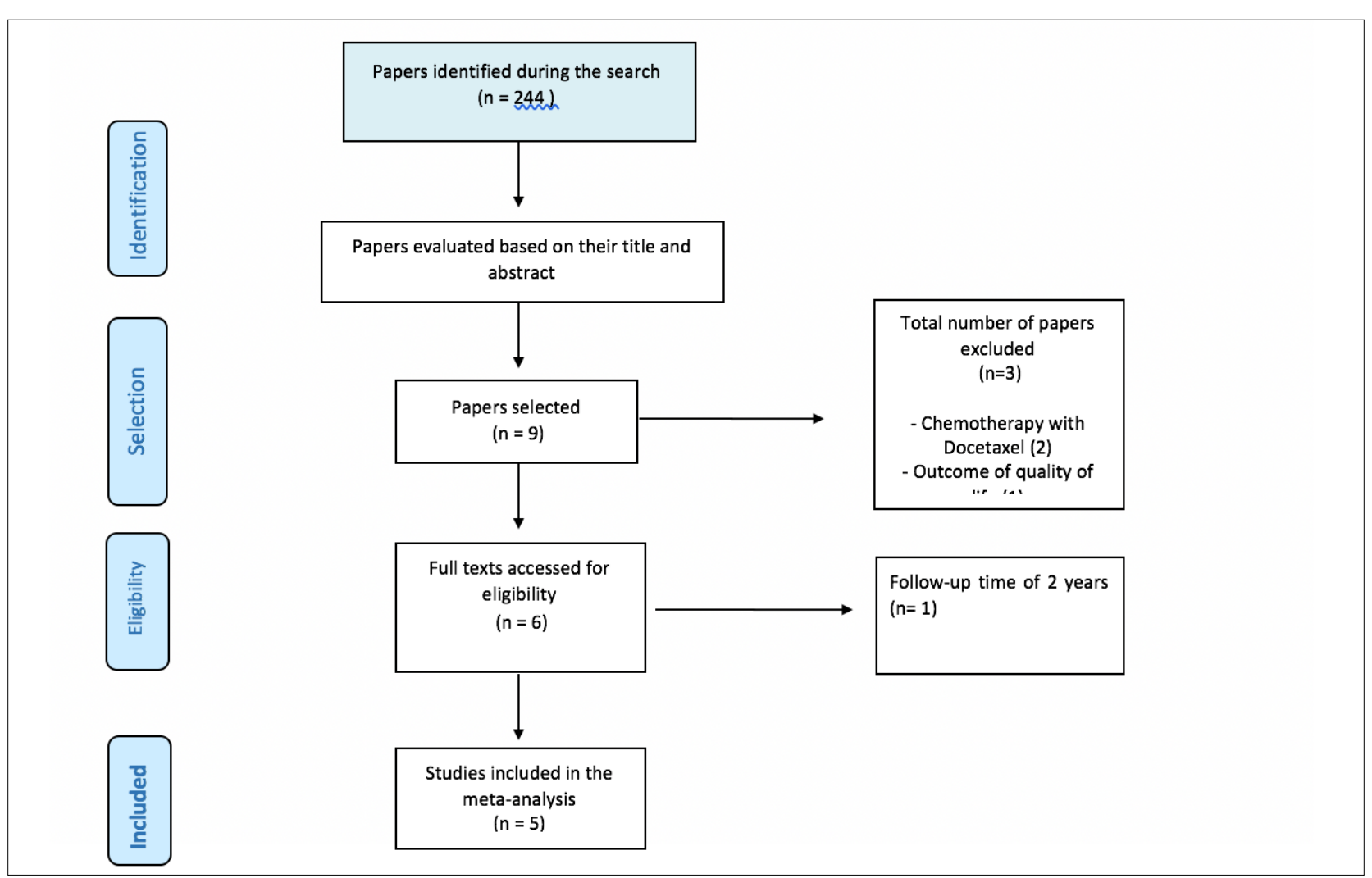


TABLE 9. STUDIES EXCLUDED AND REASON FOR EXCLUSION

\begin{tabular}{|l|l|}
\hline Study & \multicolumn{1}{l|}{ Reason for exclusion } \\
\hline Barlesi F, et al. 2019 & $\begin{array}{l}\text { Docetaxel intervention and } \\
\text { quality of life outcome }\end{array}$ \\
\hline Reck M, et al. 2019 & Follow-up time of 2 years \\
\hline Brahmer JR, et al. 2017 & Outcome of quality of life \\
\hline Herbst RS, et al. 2016 & Docetaxel intervention \\
\hline
\end{tabular}

\section{Application of evidence - Recommendation}

The available evidence will follow some principles of exposure- it will be by outcome and will have as components: number of patients, type of comparison, magnitude, and precision (standard deviation and $95 \% \mathrm{CI}$ ).

Its strength will be estimated (Oxford ${ }^{16} / \mathrm{Grade}^{8}$ ) as
$1 \mathrm{~b}$ and $1 \mathrm{c}$ (grade A) or strong, and as $2 \mathrm{a}, 2 \mathrm{~b}$ and $2 \mathrm{c}$ (grade B) or moderate weak, or very weak.

\section{Conflict of interest}

There is no conflict of interest related to this review that can be declared by any of the authors.

\section{Final declaration}

The Guidelines Project, an initiative of the Brazilian Medical Association in partnership with the Specialty Societies, aims to reconcile medical information in order to standardize approaches that can aid the physician's reasoning and decision-making process. The information contained in this project must be submitted to the evaluation and criticism of the physician responsible for the conduct to be followed, given the reality and clinical condition of each patient.

\section{REFERENCES}

1. Mok TSK, Wu YL, Kudaba I, Kowalski DM, Cho BC, Turna HZ, et al. Pembrolizumab versus chemotherapy for previously untreated, PD-L1-expressing, locally advanced or metastatic non-small-cell lung cancer (KEYNOTE-042): a randomized, open-label, controlled, phase 3 trial. Lancet 2019 4;393:1819-1830. PMID: 30955977

2. Reck M, Rodríguez-Abreu D, Robinson AG, Hui R, Csőszi T, Fülöp A, et al. Pembrolizumab versus Chemotherapy for PD-L1-Positive Non-Small-Cell Lung Cancer. N Engl J Med 2016 10;375:1823-1833. PMID: 27718847

3. Langer Cl, Gadgeel SM, Borghaei H, Papadimitrakopoulou VA, Patnaik A, Powell SF, et al. Carboplatin and pemetrexed with or without pembrolizumab for advanced, non-squamous non-small-cell lung cancer: a randomized, phase 2 cohort of the open-label KEYNOTE-021 study. Lancet Oncol 2016;17:1497-1508. PMID: 27745820

4. Gandhi L, Rodríguez-Abreu D, Gadgeel S, Esteban E, Felip E, De Angelis $F$, et al. Pembrolizumab plus Chemotherapy in Metastatic Non-Small-Cell Lung Cancer. N Engl J Med 2018 31;378:2078-2092. PMID: 29658856

5. Paz-Ares L, Luft A, Vicente D, Tafreshi A, Gümüş M, Mazières J, et al. Pembrolizumab plus Chemotherapy for Squamous Non-Small-Cell Lung Cancer. N Engl I Med 2018 22;379:2040-2051. PMID: 30280635

6. GRADEpro GDT: GRADEpro Guideline Development Tool [Software]. McMaster University, 2015 (developed by Evidence Prime, Inc.). Available from gradepro.org.

7. Jadad AR, Moore RA, Carroll D, Jenkinson C, Reynolds DI, Gavaghan D|, et al. Assessing the quality of reports of randomized clinical trials: is blinding necessary? Control Clin Trials 1996; 17:1-12.

8. Review Manager (RevMan) [Computer program]. Version 5.3. Copenhagen:

The Nordic Cochrane Centre, The Cochrane Collaboration, 2014

9. Oxman A, Guyatt G. When to believe a subgroup analysis. In: Guyatt G. User's guides to medical literature. A manual of evidence based clinical pratice. New York: Jama Press, 2003.

\section{REFERENCES ANNEXES}

1. Barlesi F, Garon EB, Kim DW, Felip E, Han JY, Kim JH, et al. Health-Related Quality of Life in KEYNOTE-010: a Phase II/III Study of Pembrolizumab Versus Docetaxel in Patients With Previously Treated Advanced, Programmed Death Ligand 1-Expressing NSCLC. | Thorac Oncol 2019;14:793801. PMID: 30711649

2. Reck M, Rodríguez-Abreu $D$, Robinson AG, Hui R, Csőszi T, Fülöp A, Gottfried M, et al. Updated Analysis of KEYNOTE-024: Pembrolizumab Versus Platinum-Based Chemotherapy for Advanced Non-Small-Cell Lung Cancer With PD-L1 Tumor Proportion Score of 50\% or Greater. J Clin Oncol 2019 1;37:537-546. PMID: 30620668

3. Brahmer JR, Rodríguez-Abreu D, Robinson AG, Hui R, Csőszi T, Fülöp $A$, Gottfried M, et al. Health-related quality-of-life results for pembrolizumab versus chemotherapy in advanced, PD-L1-positive NSCLC (KEYNOTE-024): a multicentre, international, randomised, open-label phase 3 trial. Lancet Oncol 2017;18:1600-1609. PMID: 29129441

4. Herbst RS, Baas P, Kim DW, Felip E, Pérez-Gracia JL, Han JY, et al. Pembrolizumab versus docetaxel for previously treated, PD-L1-positive, advanced non-small-cell lung cancer (KEYNOTE-010): a randomised controlled trial. Lancet 2016 9;387:1540-50. PMID: 26712084 